\title{
Van İlinde Yaşayanların Trafik İşaretleri Bilgisi ve Trafik Kurallarına Bakış Açıları Üzerine Bir Araştırma
}

\author{
Sanem Şehribanoğlu ${ }^{*}$ \\ ${ }^{1}$ Fen Fakültesi İstatistik Bölümü, Van Yüzüncü Y1l Üniversitesi, Van Türkiye.
}

$\ddot{\mathbf{O} z}$

Dünya Sağlık Örgütü'nün raporuna göre her yıl dünyada 1.35 milyondan fazla insan trafik kazaları sonucu hayatını kaybetmektedir. Yirmi ile elli milyondan fazla insan ölümle sonuçlanmayan kazalar yaşamakta ve bu kazalar bireylerin, ailelerin ve ülkelerin ekonomik kayıplarıyla sonuçlanmaktadır. Trafik kazalarına neden olan sebeplerin başında; sürücü, yolcu ve yaya davranışlarından oluşan insan etkeni gelmektedir. Trafikte insan etkeni, davranış farklılıklarından dolayı, karmaşık değerlendirmeler yapılmasını gerektirmektedir. Bu çalışmanın amacı: 2014 2017 yılları arasında Van il merkezinde yaşayan (sürücü veya yaya) bireylerin, trafik işaretleri ile ilgili bilgi ve farkındalık düzeylerinin ölçülmesi ile trafik kurallarına bakış açılarının değerlendirilmesidir. Toplam 650 kişi ile anket uygulaması yapılarak gerçekleştirilmiş olan çalışmada, bireylerin trafik işaretlerine bakış açılarını değerlendirmek üzere 18 trafik işaretinin anlamına yönelik soruların yanı sıra 5'li likert ölçek tipi sorular sorulmuştur. Anket sonuçları istatistiksel yöntemlerle (iki örneklemli t-testi ve ANOVA) değerlendirilmiş ve Van iline ilişkin bazı çıkarımlar yapılmıştır.

Anahtar Kelimeler: Van, trafik işaretleri, trafik kuralları, trafikte farkındalık

\section{Research into the Knowledge of Traffic Signs and Attitude to Traffic Rules among Those Living in Van}

\begin{abstract}
According to the World Health Organization report, each year, more than 1.35 million people die as a result of traffic accidents in the world. More than twenty to fifty million non-lethal accidents occur and these accidents result in economic losses to individuals, families and countries. Leading the causes of traffic accidents is the human factor comprising behavior of drivers, passengers and pedestrians. When the human factor is mentioned in relation to traffic, different variables occur due to the complex structure of humans. The target was to measure the knowledge and awareness levels of individuals (drivers or pedestrians) living in Van city center from 2014 to 2017 about traffic signs, in addition to obtaining an idea about the attitude of these individuals to traffic rules. This study, completed with a total of 650 people, asked questions about 18 traffic signs to assess attitudes to traffic signs, in addition to asking different questions, on a 5-point Likert scale. As a result of statistical analyses (independent t-test and ANOVA), the study attempts to make inferences for the province of Van in general.
\end{abstract}

Keywords: Van, traffic signs, traffic rules, awareness in traffic

\footnotetext{
"'Iletişim / Contact: Sanem Şehribanoğlu, Fen Fakültesi İstatistik Bölümü, Van Yüzüncü Yıl Üniversitesi, Van Türkiye. E-Posta /Email: sanem@yyu.edu.tr Gönderildiği tarihi / Date submitted: 12.11.2018, Kabul edildiği tarih / Date accepted: 16.04.2019

Alıntı / Citation: Şehribanoğlu, S. (2019). Van ilinde yaşayanların trafik işaretleri bilgisi ve trafik kurallarına bakış açıları üzerine bir araştırma. Trafik ve Ulaşım Araştırmaları Dergisi, 2(1), 1-15.
} 


\section{Van İlinde Yaşayanların Trafik İşaretleri Bilgisi ve Trafik Kurallarına Bakış Açıları Üzerine Bir Araşturma}

Son yıllarda Türkiye'de motorlu taşıt sayısında artış olduğu görülmektedir. Türkiye'de 2017 ve 2016 yıllarına ait trafiğe kayıtlı toplam araç sayıları karşılaştırıldığı zaman bu değerin \%5'lik bir oranla arttığı görülmektedir. En büyük artış \%18'lik bir oran ile özel amaçlı taşıtlarda gerçekleşmiştir (Türkiye İstatistik Kurumu [TÜİK], 2018). Bu artış beraberinde; hava kirliliğí, gürültü kirliliği, trafik tıkanıklığı ve trafik kazaları gibi sorunları da getirmektedir.

2017 yılına ait kayıt altına alınan toplam kaza sayısı 1202716'dır. Bunların 182669'u ölümlü ve yaralanmalı kazalardır (Tablo 1). Emniyet Genel Müdürlüğü Trafik Eğitim ve Araştırma Dairesi Başkanlığı tarafından açıklanan 2017 raporuna (Emniyet Genel Müdürlüğü [EGM], 2017a) göre trafik kazalarına (ölümlü-yaralanmalı) neden olan unsurlar incelendiği zaman bu kazaların \%90'ı sürücü, \%8'i yaya kusurlarından kaynaklandığı görülmektedir. Van ilinde gerçekleşen trafik kazaları incelendiğinde ise, 2017 yılına ait ölümlü-yaralanmalı kaza sayısı 1337, maddi hasarlı kaza sayısı 987, ölü sayısı 22, yaralı sayısı 2568'dir. Arıkan-Öztürk (2016), 2013 yılı verilerini kullanarak Türkiye'deki illerin trafik risk endeksini (trafik kazaları göstergeleri, yol kullanıcı göstergeleri, sistem göstergeleri ve demografik göstergeleri kullanarak) hesapladığı çalışmasında; Van ilini 21.05 puanla en riskli 19. il olarak belirlemiştir.

Türkiye Büyük Millet Meclisi (TBMM) Dilekçe Alt Komisyonu'nun raporuna göre; Türkiye "Trafik kazalarında can kayıpları Avrupa Birliği üye ülkelerinden en az 5 kat daha fazladır" (Birgün, 2018). "Türkiye'de her yıl yedi bini aşkın kişi, trafik kazalarında hayatını kaybederken yaklaşık üç yüz bin kişi de yaralanmaktadır. Yaralananlardan bazıları ömürleri boyunca engelli kalmaktadır. Yaşanan kazalar, bu kişilerin yaşamlarının önemli bir bölümünün tamamen veya kısmen yok olması anlamını taşımaktadır. Karayollarında meydana gelen trafik kazaları makro ölçekte ülke ekonomilerine, mikro ölçekte şehir ekonomilerine büyük maliyetler yüklemektedir" (Karabağgl, 2018).

Trafik kazalarına ilişkin kusurlar beş başlık altında toplanmaktadır. Bunlar; sürücü, yolcu, yaya, yol ve araç kusurudur. Trafik kazalarına neden olan en önemli etmenlerin başında insan (sürücü, yolcu ve yaya) unsuru gelmektedir. Trafik kazalarına neden olan unsurlar incelendiğinde (Tablo 2), 2017 yılında ilk sıraları sürücü ve yaya kusurlarının aldığı, daha önceki yıllarda da sürücü kusurlarının yüksek olduğu görülmektedir. Dünya genelinde ciddi bir sorun olarak kabul edilen trafik kazaları, Türkiye'de de can, mal, zaman ve işgücü kaybının yanı sıra ailelerde oluşan yıkımlar da dikkate alındığında önemli bir toplumsal sorun olarak karşımıza çıkmaktadır.

Trafikte bilgi, algılama ve farkındalık kavramları, trafik güvenliğinin sağlanabilmesi açısından önemlidir. Sürücülerin trafik işaretlerini anlamaları ve buna göre davranmaları trafikte güvenli sürüşü etkileyen faktörler arasındadır (Kırmızıoğlu ve Tüydeş-Yaman, 2012).

13.10.1983 tarih ve 2918 sayılı Karayolları Trafik Kanunu'nda yer verilmiş olan tanımlara göre trafik işaretleri, "Trafiği düzenleme amacı ile kullanılan işaret levhaları, ş̧ıklı ve sesli işaretler, yer işaretlemeleri ile trafik zabıtası veya diğer yetkililerin trafiği yönetmek için yaptıkları hareketler" işaret levhası ise, "sabit veya taşınabilir bir mesnet üzerine yerleştirilmiş ve üzerindeki sembol, renk ve yazı ile özel bir talimatın aktarılmasını sağlayan trafik tertibatı" olarak tanımlanmıştır (T.C. Cumhurbaşkanlığı Hukuk ve Mevzuat Genel Müdürlüğü [Mevzuat], 2018). Trafik işaretleri ihtiyaca cevap vermek, dikkat çekmek (Al-Madani ve AlJanahi, 2002), araç hareketlerinin kontrol edilmesi, trafik sorunlarının azaltılması ve trafik akış kalitesinin iyileştirilmesi (Kazemi, Rahmi ve Roshankhah, 2016) amaciyla gerekli ve etkindir.

\section{TQD}


Tablo 1. Yıllara göre kaza, ölü ve yaralı sayısı (TüIK, 2018)

\begin{tabular}{|c|c|c|c|c|c|c|c|}
\hline \multirow[b]{2}{*}{ Y1l } & \multirow[b]{2}{*}{$\begin{array}{c}\text { Toplam } \\
\text { kaza sayısı }\end{array}$} & \multirow[b]{2}{*}{$\begin{array}{c}\text { Maddi hasarlı } \\
\text { kaza sayısı }\end{array}$} & \multirow[b]{2}{*}{$\begin{array}{c}\text { Ölümlü, } \\
\text { yaralanmalı } \\
\text { kaza sayısı }\end{array}$} & \multicolumn{3}{|c|}{ Ölü sayısı* } & \multirow[b]{2}{*}{ Yaralı sayıs1 } \\
\hline & & & & Toplam & $\begin{array}{c}\text { Kaza } \\
\text { yerinde }\end{array}$ & $\begin{array}{c}\text { Kaza } \\
\text { sonrası }\end{array}$ & \\
\hline 2010 & 1106201 & 989397 & 116804 & 4045 & 4045 & - & 211496 \\
\hline 2011 & 1228928 & 1097083 & 131845 & 3835 & 3835 & - & 238074 \\
\hline 2012 & 1296634 & 1143082 & 153552 & 3750 & 3750 & - & 268079 \\
\hline 2013 & 1207354 & 1046048 & 161306 & 3685 & 3685 & - & 274829 \\
\hline 2014 & 1199010 & 1030498 & 168512 & 3524 & 3524 & - & 285059 \\
\hline 2015 & 1313359 & 1130348 & 183011 & 7530 & 3831 & 3699 & 304421 \\
\hline 2016 & 1182491 & 997363 & 185128 & 7300 & 3493 & 3807 & 303812 \\
\hline 2017 & 1202716 & 1020047 & 182669 & 7427 & 3534 & 3893 & 300383 \\
\hline
\end{tabular}

* Ölü saylları 2015 yllına kadar sadece kaza yerinde tespit edilen ölümleri kapsarken, 2015 yılından itibaren trafik kazasında yaralanıp sağlık kuruluşuna sevk edilenlerden kazanın sebep ve tesiriyle 30 gün içinde ölenleri de kapsamaktadir.

Tablo 2. Trafik kazalarına neden olan kusur oranları (\%) (TÜIK, 2018)

\begin{tabular}{cccccc}
\hline Y1l & Sürücü kusuru & Yolcu kusuru & Yaya kusuru & Yol kusuru & Araç kusuru \\
\hline 2010 & 89.72 & 0.36 & 9.86 & 0.69 & 0.36 \\
2011 & 90.20 & 0.39 & 8.51 & 0.60 & 0.30 \\
2012 & 88.86 & 0.44 & 9.75 & 0.62 & 0.33 \\
2013 & 88.69 & 0.42 & 8.99 & 1.05 & 0.85 \\
2014 & 88.62 & 0.47 & 9.38 & 0.95 & 0.58 \\
2015 & 89.30 & 0.43 & 8.80 & 0.91 & 0.55 \\
2016 & 89.59 & 0.41 & 8.73 & 0.81 & 0.47 \\
2017 & 89.87 & 0.37 & 8.48 & 0.70 & 0.52 \\
\hline
\end{tabular}

Sürücülerin trafik işaretlerinde kodlanan bilgileri eksik ya da yanlış anlaması, amaçlanan faydaları azaltabilir (Razzak ve Hasan, 2010). Hatta daha da kötüsü, bir trafik işareti kazanın meydana gelmesi için ana sebeplerden biri olabilir (Zhang ve Chan, 2013). Trafiğin güvenli ve düzenli akışının sağlanması için, trafik işaretlerinin standartlara uygun ve yerinde kullanılmasının yanı sıra, anlamlarının da kullanıcılar tarafından yeterince bilinir ve anlaşılır olması gerekmektedir (Murat ve Çakı1, 2017).

Bir konunun öğrenilebilmesi; cinsiyet, yaş, öğrenim durumu, ekonomik ve kültürel değerlere bağlı olarak değişim gösterdiği bilinmektedir. Buna karşın, Luoma ve Rama'nın (1998) trafik işaretlerinin anlaşılabilirliği üzerine gerçekleştirdiği çalışmalarda, trafik işaretlerinin algılanmasında yaş, cinsiyet ve deneyimin bir etkisinin bulunmadığı saptanmıştır. Al-Madani ve Al-Janahi (2002), Bahreyn, Kuveyt, Umman, Katar ve Birleşik Arap Emirlikleri'nde 9000 sürücünün kişisel ve sosyal özelliklerini (deneyim, kaza sayısı, medeni durum, cinsiyet, yaş, milliyet, eğitim ve gelir düzeyi) dikkate alarak trafik işaretlerinin bilinirliğini araştırmışlardır. Çalışma sonucunda yaş, cinsiyet, eğitim ve gelir unsurlarının trafik işaretlerinin bilinirliğinde öneme sahip olduğu belirlenmiştir. Ayrıca, kültürler arasında, trafik işaretlerinin bilinirlik düzeylerinde fark olduğu da saptanmıştır. Kanada, Finlandiya, İsrail ve Polonya da her ülkeden 250 kişinin katılımıyla Shinar, Dewar, Summala ve Zakowska (2003) tarafından

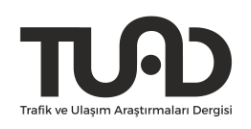


gerçekleştirilen çalışmada, 31 trafik işaretinin anlamının farklı ülkelerdeki sürücüler arasında farklılaştığı yani; kültür farklılıklarının trafik işaret algısında etkili olduğu ortaya koyulmuştur. Ayrıca çalışma bulgularına göre genç sürücüler yaşlı sürücülere göre trafik işaretlerini daha iyi tanımaktadır. Ng ve Chan (2008) çalışmalarında, sürücülerin kişisel özellikleri, işaretlerin tasarım özellikleri hakkında aldıkları not ve işaretlerin bilinirlik puanlarını da kapsayan bir anket kullanmışlardır. Yüz dokuz Hong-Kong'lu ehliyet sahibine uygulanan bu çalışmanın sonucunda, eğitim düzeyleri ve ehliyet sahibi oldukları süre bilgilerinin anlamlı bir gösterge olduğu görülmüş ve bunlarla işaretlerin anlaşılması arasında anlamlı bir ilişki olduğu saptanmıştır. Razzak ve Hasan (2010), Bangladeş'in başkenti Dakka'da sürücülerin trafik işaretlerinin bilinirliğini incelemek için yaptıkları çalışmada, yaş ve eğitimin doğru cevapları vermekte anlamlı olduğu ve bu kapsamda trafik işaretlerinin bilinirliğini artırmak için eğitimin gerekli olduğu sonucuna varmışlardır. Kırmızıŏ̆lu ve Tüydeş-Yaman (2012), Türkiye'deki sürücüler arasında trafik işaretlerinin anlaşılabilirliği üzerine bir çalışma yapmışlardır. Ankara'daki 1478 sürücü ile yapılan çalışmada, 30 adet farklı trafik işaretini içeren bir anket kullanılmıştır. Sürücülerin yaş, cinsiyet, eğitim durumu, meslek, ehliyet sınıfı, ehliyet sahibi oldukları süre, şehir içi ve şehir dışında yıllık ortalama araç kullanma uzunlukları, son beş yılda aldığı ceza sayısı da dikkate alınan çalışmada, sürücülerin trafik işaretlerini bilme düzeyleri yetersiz bulunmuştur. Kazemi ve arkadaşları (2016), İran'ın kuzeyindeki Ruodsar ve Ramsar kenti arasında 527 sürücünün günlük olarak görülen trafik işaretlerine olan dikkat düzeylerini belirlemeye çalışmışlardır. Çalışmada trafik işaretlerinin algılanması üzerinde yaş ile deneyim arasında önemli bir ilişki olduğuna dikkat çekilirken, trafik işaretlerine verilen cevapların gelişmesi için eğitimin gerekli olduğu sonucuna varılır.

Emniyet Genel Müdürlüğü web sayfasından alınan bilgiler doğrultusunda 2017 yılında Van ilindeki toplam sürücü sayısı 221757'dir (EGM, 2017b). Van ilindeki toplam araç sayısı 79327 iken, otomobil sayısı 27942'dir (TÜİK, 2018). İldeki araç sayısı Türkiye toplamının \%0.4'ünü oluşturmaktadır. Van İli Trafik Şube Müdürlügü'ne kayıtlı toplam 27872 otomobil bulunmaktadır. Farklı bir ilde kayıtlı araca sahip olan ve Van ilinde yaşamını devam ettiren kişiler bu sayının dışında yer almaktadır. Benzer şekilde, Van iline kayıtlı olup, başka illerde yaşayan kişiler de olabileceği göz önüne alınabilir.

Türkiye'nin birçok ilinde trafik işaretleri bilgisi (Kartal ve Batmaz, 2007; Kırmızıoğlu ve Tüydeş-Yaman, 2012; Murat ve Çakıc1, 2017) veya trafik kurallarına bakış (Eşiyok, Yasak ve Korkusuz, 2007; Girgin ve Kocabıyık, 2003; Nordfjaern ve Şimşekoğlu, 2014; Öztürk ve Özkan, 2018; Yıldız ve Karaca, 2004; Yılmaz ve Çelik, 2006), farklı bakış açılarıyla ölçülmeye, anlaşılmaya çalışılmıştır. Ancak Van ilinde bu kapsamda bir çalışma daha önce yapılmamıştır. Bu kapsamda gerçekleştirilen ilk çalışma olan bu makalenin temel amacı, Van ilinde yaşayan (sürücü ve yaya) bireylerin trafik işaretleri ile ilgili bilgi ve farkındalık düzeylerinin ölçülmesi ile trafik kurallarına bakış açılarının değerlendirilmesidir.

\section{Yöntem}

\section{1. Örneklem}

Çalışmanın örneklemi, 2014-2017 yılları arasında Van il merkezinde rastgele örnekleme yöntemiyle, farklı zaman ve bölgelerde anketörler yardımıyla, doldurulan anketlerin yanı sıra Van Yüzüncü Y1l Üniversitesi'nin (YYÜ) internet sitesinden elde edilen anketler dâhil olmak üzere toplamda 650 kişiden oluşmaktadır.

\subsection{Veri Toplama Araçları}

Bu çalışmada Yakut'un (2006) tez çalışmasında kullanmış olduğu 18 trafik işareti kullanılarak, işaretlerin bilinirlik düzeyleri ölçülmeye çalışılmıştır. Ayrıca çalışmaya katılan kişilerin trafiğe

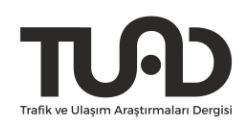


bakış açılarını değerlendirmek üzere Yılmaz ve Çelik'in (2006) Eskişehirli sürücüler üzerine yaptıkları anket sorularından yararlanılmıştır. Bu sorular Reason, Manstead, Stradling, Baxter ve Campbell (1990) tarafindan geliştirilen sürücü davranışı ile Ulleberg ve Rundmo (2003) tarafindan geliştirilen, trafik güvenliği ve sürücülerin riskli davranış tutumları anketlerinden alınmıştır. Anket hakkında Van İl Trafik Şube Müdürlüğü’nün de görüşlerine başvurulmuştur.

Katılımcıların, trafikle ilgili tutumlarının ölçülmesi için bu çalışmada 5'li likert ölçek tercih edilmiştir. Kullanılan likert ölçeklerde, açık ve tek bir yargı şeklinde sorulan sorulara katılımcilardan 1-kesinlikle katılmıyorum, 2-katılmıyorum, 3-kararsızım, 4-katıliyorum, 5kesinlikle katıliyorum seçeneklerinden birini tercih ederek cevap vermeleri istenmiştir. Genel olarak katılımcıların tutumlarını anlayabilmek için likert puanlarının aritmetik ortalamalarına ve standart sapmalarına yer verilmiştir.

\section{3. İşlem}

Bu çalışmada demografik bilgilerin yanı sıra katılımcıların verdikleri cevapların demografik özelliklerine göre anlamlılıkları incelenmiş, bunun için tanımlayıcı istatistiklerin yanı sıra iki bağımsız örneklem arasındaki farkın anlamlılığı testi ( $\mathrm{t}$ testi) ve tek yönlü varyans analizi (ANOVA - F testi) uygulanmıştır. Varyans analizi sonuçlarında farklılıkların tespiti için PostHoc testlerinden olan Tukey testinden yararlanılmıştır. Ayrıca bu çalışmada karar ağaçlarından CHAID analizi kullanılmıştır. Karar ağacı, ağaç yapısına sahip tahminsel bir yöntemdir. Çok değişkenli istatistiksel yöntemler için gerekli olan değişkenlerin normallik, doğrusallık, homojenlik gibi varsayımlarına ihtiyaç duymamaktadır. CHAID analizi bağımlı değişken ile bağımsız değişkenler arasındaki ilişkiyi belirleyebildiği gibi, bağımsız değişkenlerin birbirleriyle olan etkileşimlerini de ortaya çıkarabilme özelliğine sahiptir (Üngüren ve Doğan, 2010). Ancak verileri homojen gruplara ayırırken kullanılan bağımlı değişken sürekli ise F testi, kategorik ise ki-kare testi kullanarak alt düğümleri oluşturur (Şehribanoğlu ve Diler, 2018). CHAID analizi uygulamalarında likertli ölçeklerde yorumlama kolaylığı sağlanabilmesi için puanlar, 1-kesinlikle katılmiyorum ve 2-katılmıyorum puanları 1-katılmıyorum olarak, 3kararsızım, 2-kararsızım olarak ve 4-katılıyorum ile 5-kesinlikle katıliyorum puanları 3katıliyorum olarak yeniden kodlanmıştır.

\section{Sonuçlar}

Bu çalışmanın katılımcılarının 254'ü (\%39) kadın, 396'sı (\%61) ise erkektir. Katılımcıların \%61'i (397) ehliyet sahibi olduklarını, \%39'u (253) ehliyet sahibi olmadıklarını beyan etmiştir. Çalışmaya katılanların yaş ortalamaları Ort. $=28$, standart sapması $S S=9.5^{\prime}$ dir. Şehrin genç bir nüfusa sahip olması ve gençlerin anketleri cevaplama isteği göz önüne alındığında, anketlere katılanların \%49'unun 18-25 yaş aralığında olması beklenen bir sonuçtur. Yine aynı sebeplerden dolayı ankete katılanların \%26'sı öğrenci, \%20'si memur iken, en yüksek öğrenim durumu \%61 ile üniversite/yüksek okuldur. Katılımcılara ait demografik bilgiler Tablo 3'de görülmektedir. Ehliyet sahibi olanlardan 352 kişi (\%89) B sınıfı ehliyete sahip olduklarını beyan etmiştir. Ehliyet sahibi katılımcıların 176'sı (\%27) kadın, 474'ü (\%73) erkektir.

$\mathrm{Bu}$ çalışmanın katılımcıları, trafik işaretlerini okuma ve anlama becerisine sahibim sorusuna (2-katılmıorum ve 1-kesinlikle katılmıyorum) toplamda \%68 oranında (442 kişi) katılmadıklarını beyan etmiştir. Bu soru, ankete katılanlar tarafından ortalama $($ Ort. $=2, S S=$ 1.28) puan aldığından, katılımcıların bu tutuma katılmadıkları sonucuna ulaşılmıştır. Ayrıca sorulara doğru cevap veremeyen 48 kişinin (\%7) yanı sıra trafik işareti sorularının tamamını cevaplayabilen bulunmamıştır.

Tablo 5'de trafik işaretlerine verilen cevapların yüzde değerleri ve soruya yanıt vermek istemeyen kişi sayılarına yer verilmiştir. Bu tabloda en ilgi çekici noktalardan biri on beşinci

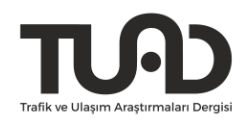


soruya cevap veren katılımciların \%70'inin yanlış cevap vermesidir. Sekizinci, birinci ve on üçüncü sorulara sırasıyla 170, 135, 103 kişi cevap vermemiştir.

Verilen cevaplar cinsiyetlere göre incelenecek olursa kadınların doğru cevapladıkları trafik işareti sayısı ortalama 5 iken, erkeklerde bu sayı 8 olmuştur. On ve ondan daha fazla trafik işaretleri bilenlerin sayısı 138 kadın (\%21) iken bu sayı erkeklerde 289 (\%45) olmuştur. Cinsiyet $(t=2.86, p=0.04)$ ve öğrenim durumu $(F(5,644)=5.00, p=0.01)$ arasında trafik işaretleri bilinirliği açısından anlamlı bir fark saptanmıştır. Öğrenim durumları bakımından bu farklılığın hangi eğitim durumundan kaynaklandığını görebilmek için yapılan Post-Hoc testlerinden Tukey test sonuçlarına göre, üniversite ve yüksek lisans mezunlarının daha doğru cevaplar verdiği görülür. Ehliyet sahibi olanların ortalama olarak doğru cevapladıkları trafik işareti sayısı 7'de kalırken, ehliyet sahibi olmayanların ortalama olarak doğru cevapladıkları trafik işareti sayısı 5 'dir. Gruplar arasında trafik işaretleri tanınırlığı açısından anlamlı bir fark olduğu $(t=5.23, p=0.00)$ saptanmıştır.

Tablo 3. Katılımcılara ait demografik bilgiler

\begin{tabular}{|c|c|c|c|c|c|c|c|c|c|c|}
\hline Yaş & $18-25$ & $26-33$ & $34-41$ & $42-49$ & $50-57$ & $58-65$ & $66-73$ & $74-81$ & & Toplam \\
\hline $\begin{array}{l}\text { Katılımc1 } \\
\text { Sayıs1 }\end{array}$ & 320 & 169 & 103 & 40 & 6 & 6 & 3 & 3 & & 650 \\
\hline $\begin{array}{l}\text { Mesleki } \\
\text { Durum }\end{array}$ & Öğrenci & Öğretmen & Akademisyen & Memur & İşçi & $\begin{array}{l}\text { Serbest } \\
\text { Meslek }\end{array}$ & Mühendis & Şoför & Diğer & Toplam \\
\hline $\begin{array}{l}\text { Katılıme1 } \\
\text { Sayıs1 }\end{array}$ & 168 & 39 & 52 & 130 & 13 & 59 & 26 & 13 & 150 & 650 \\
\hline $\begin{array}{l}\text { Öğrenim } \\
\text { Durumu }\end{array}$ & İlkokul & Ortaokul & Lise & $\begin{array}{c}\text { Üniversite } \\
\text { Y.Okul }\end{array}$ & Lisansüstü & - & - & - & - & Toplam \\
\hline $\begin{array}{l}\text { Katılımc1 } \\
\text { Sayıs1 }\end{array}$ & 26 & 39 & 92 & 395 & 98 & - & - & - & - & 650 \\
\hline $\begin{array}{l}\text { Ehliyet } \\
\text { Türleri }\end{array}$ & A2 & B & $\mathrm{C}$ & $\mathrm{E}$ & Ehliyetsiz & - & - & - & - & Toplam \\
\hline $\begin{array}{l}\text { Katılımc1 } \\
\text { Sayıs1 }\end{array}$ & 10 & 352 & 3 & 32 & 253 & - & - & - & - & 650 \\
\hline
\end{tabular}

Tablo 4. Bazı anket sorularının dĕgerlendirilmesi

\begin{tabular}{|c|c|c|c|c|c|c|c|c|c|c|}
\hline & Genel & Ehliye & sahipliği & Cin & siyet & & & Öğre & im Durumu & \\
\hline & Katılımcilar & Sahip & Sahip Değil & Erkek & Kadın & İlkokul & Ortaokul & Lise & Üniversite/Y.Okul & Lisansüsti \\
\hline Trafi & kurallarına he & rfi harfi & le uymak gere & & & & & & & \\
\hline Ort. & 2.6 & 2.6 & 2.6 & 2.8 & 2.6 & 2.8 & 2.7 & 2.5 & 2.5 & 2.8 \\
\hline$S S$ & 1.3 & 1.3 & 1.2 & 1.2 & 1.3 & 1.6 & 1.1 & 1.4 & 1.3 & 1.2 \\
\hline Zam & Inda varmak & çin baze & $\mathrm{n}$ trafik kurall & arını esn & etmenin & bir sakın & cas1 yoktu1 & & & \\
\hline Ort. & 2.8 & 2.7 & 2.9 & 2.7 & 2.8 & 3.2 & 3.4 & 2.4 & 2.7 & 2.8 \\
\hline$S S$ & 1.1 & 1.1 & 1.1 & 1.2 & 1.1 & 1.2 & 0.9 & 1.1 & 1.1 & 1.1 \\
\hline Emn & et kemerinin & layati bi & önem taşıdığ & Ina inan & yorum & & & & & \\
\hline Ort. & 2.3 & 2.3 & 2.5 & 2.4 & 1.4 & 2.3 & 2.5 & 2.4 & 2.3 & 1.6 \\
\hline$S S$ & 0.9 & 1.5 & 1.6 & 1.4 & 1.2 & 1.5 & 0.8 & 0.5 & 0.3 & 1.5 \\
\hline Baze & trafik kuralla & Inın çiğ & enmesini göz & ardi etn & lek gere & & & & & \\
\hline Ort. & 2.8 & 2.2 & 2.4 & 2.7 & 2.2 & 2.7 & 2.2 & 2.7 & 2.2 & 1.8 \\
\hline$S S$ & 0.9 & 1.3 & 1.4 & 1.2 & 1.2 & 1.6 & 0.9 & 0.5 & 0.4 & 1.6 \\
\hline
\end{tabular}


Tablo 4. Devam

\begin{tabular}{|c|c|c|c|c|c|c|c|c|c|c|}
\hline \multicolumn{11}{|c|}{ Bir yaya olarak tüm trafik kurallarına harfi harfine uyarım } \\
\hline Ort. & 2.7 & 2.7 & 2.8 & 2.9 & 3.1 & 3.3 & 3.5 & 2.4 & 2.7 & 2.6 \\
\hline$S S$ & 1.2 & 1.2 & 1.2 & 1.2 & 1.2 & 1.2 & 1.2 & 1.3 & 1.3 & 1.3 \\
\hline \multicolumn{11}{|c|}{ Trafikte bazen risk almak gerekir } \\
\hline Ort. & 2.8 & 2.7 & 2.6 & 2.8 & 2.6 & 2.8 & 2.5 & 2.6 & 2.8 & 2.7 \\
\hline$S S$ & 0.9 & 1.2 & 1.4 & 1.3 & 1.4 & 0.9 & 0.6 & 0.4 & 0.2 & 0.8 \\
\hline \multicolumn{11}{|c|}{ Trafik kazalarının bir kader olduğuna inanıyorum } \\
\hline Ort. & 3.9 & 3.9 & 3.3 & 3.9 & 3.4 & 4.1 & 3.8 & 3.9 & 3.9 & 4.1 \\
\hline$S S$ & 0.9 & 1.7 & 1.3 & 1.2 & 1.3 & 0.8 & 0.5 & 0.3 & 0.2 & 0.7 \\
\hline \multicolumn{11}{|c|}{ Trafik işaretlerinin gereksiz yere fazla olduğunu düşünüyorum } \\
\hline Ort. & 4.1 & 4.0 & 3.8 & 4.1 & 3.9 & 3.9 & 3.8 & 3.8 & 4.1 & 4.3 \\
\hline$S S$ & 0.9 & 1.4 & 1.1 & 1.3 & 1.2 & 1.4 & 1.1 & 0.5 & 0.4 & 1.8 \\
\hline \multicolumn{11}{|c|}{ Ehliyet alacak kişilerin psikolojik testlerden geçmesi gerektiğine inanıyorum } \\
\hline Ort. & 3.8 & 4.0 & 3.7 & 4.0 & 4.1 & 4.0 & 3.9 & 3.8 & 4.0 & 4.1 \\
\hline$S S$ & 0.9 & 1.1 & 1.0 & 0.9 & 1.2 & 0.9 & 0.5 & 0.3 & 0.2 & 0.8 \\
\hline
\end{tabular}

Tablo 5. Ankette katılımcılara sorulan 18 trafik işaretleri ve cevaplama yüzdeleri

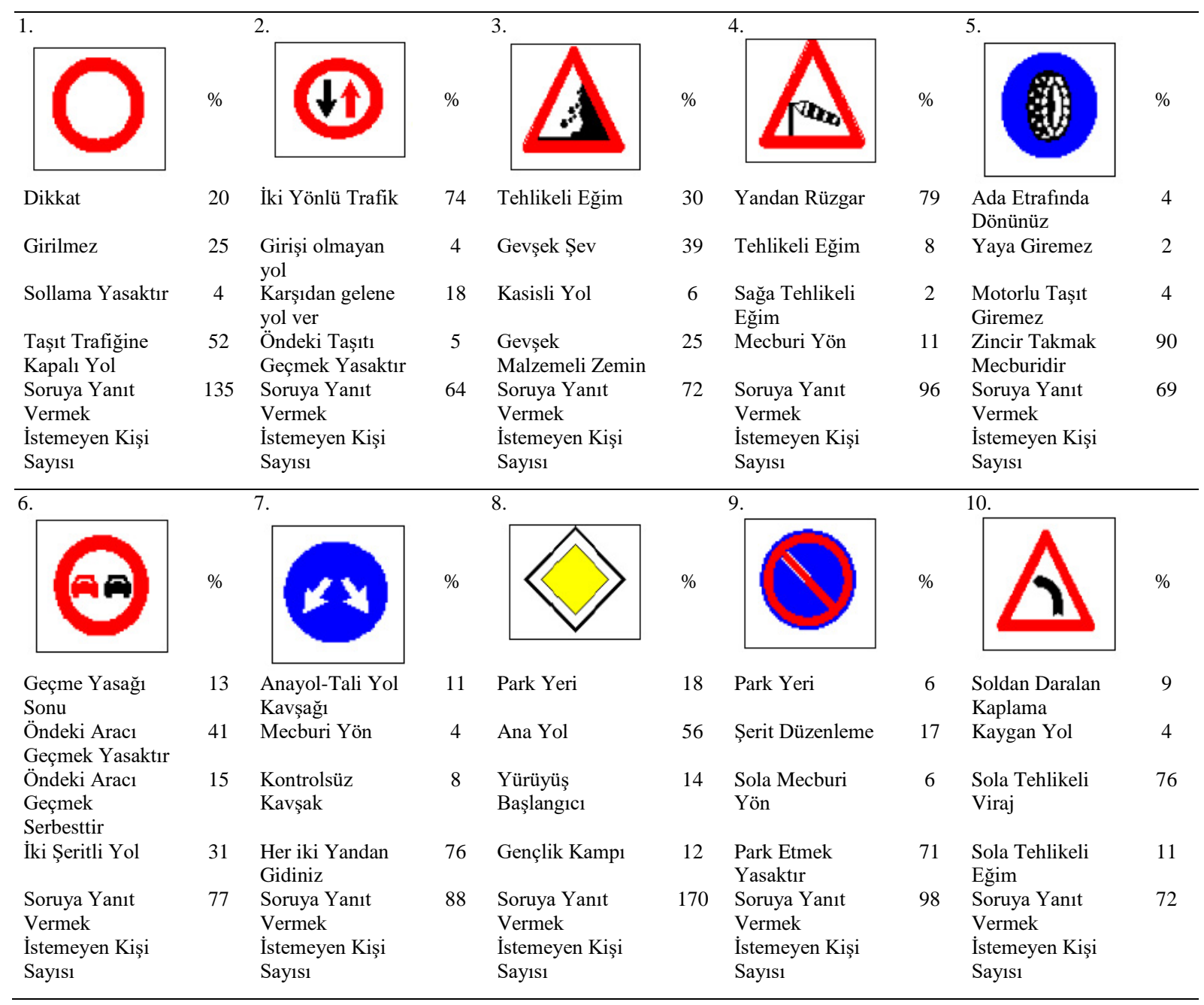


Tablo 5. Devam

\begin{tabular}{|c|c|c|c|c|c|c|c|c|c|}
\hline 11 & & 12 . & & 13. & & 14. & & 15. & \\
\hline & $\%$ & & $\%$ & & $\%$ & & $\%$ & & $\%$ \\
\hline $\begin{array}{l}\text { Gevşek } \\
\text { Malzemeli Yol }\end{array}$ & 5 & $\begin{array}{l}\text { Anayol-Tali Yol } \\
\text { Kavșağ } 1\end{array}$ & 73 & $\begin{array}{l}\text { Park Yapmak } \\
\text { Yasaktır }\end{array}$ & 20 & İleri Çıkmaz Yol & 21 & Girilmez & 41 \\
\hline Tek Yönlü Yol & 6 & İki Yönlü Yol & 9 & $\begin{array}{l}\text { Bütün Yasaklama } \\
\text { ve Kısıtlamaların } \\
\text { Sonu }\end{array}$ & 41 & Otoyol Sonu & 62 & $\begin{array}{l}\text { Kontrolsüz } \\
\text { Kavşak }\end{array}$ & 30 \\
\hline Kaygan Yol & 82 & $\begin{array}{l}\text { Kontrolsüz } \\
\text { Kavşak }\end{array}$ & 12 & Sağa Dönülmez & 3 & Otoyol Başlangıcı & 3 & Demiryolu Geçidi & 26 \\
\hline Kasisli Yol & 7 & $\begin{array}{l}\text { Taşıt Trafiğine } \\
\text { Kapalı Yol }\end{array}$ & 6 & $\begin{array}{l}\text { Trafiğe Kapalı } \\
\text { Yol }\end{array}$ & 36 & Girilmez & 14 & Dönel Kavşak & 3 \\
\hline $\begin{array}{l}\text { Soruya Yanıt } \\
\text { Vermek } \\
\text { İstemeyen Kişi } \\
\text { Sayısı }\end{array}$ & 74 & $\begin{array}{l}\text { Soruya Yanıt } \\
\text { Vermek } \\
\text { İstemeyen Kişi } \\
\text { Sayısı }\end{array}$ & 88 & $\begin{array}{l}\text { Soruya Yanıt } \\
\text { Vermek } \\
\text { İstemeyen Kişi } \\
\text { Sayısı }\end{array}$ & 103 & $\begin{array}{l}\text { Soruya Yanıt } \\
\text { Vermek } \\
\text { İstemeyen Kişi } \\
\text { Sayıs1 }\end{array}$ & 88 & $\begin{array}{l}\text { Soruya Yanıt } \\
\text { Vermek } \\
\text { İstemeyen Kişi } \\
\text { Sayısı }\end{array}$ & 85 \\
\hline 16. & & 17. & & 18. & & & & & \\
\hline $\begin{array}{l}\text { Sağa Devamlı } \\
\text { Viraj }\end{array}$ & 77 & $\begin{array}{l}\text { Bölünmüş Yol } \\
\text { Öncesi Yön }\end{array}$ & 71 & $\begin{array}{l}\text { Sağa Tehlikeli } \\
\text { Eğim }\end{array}$ & 17 & & & & \\
\hline $\begin{array}{l}\text { Sağdan Tali Yol } \\
\text { Girişi }\end{array}$ & 6 & Şerit Düzenleme & 17 & $\begin{array}{l}\text { Her iki Taraftan } \\
\text { Daralan } \\
\text { Kaplama }\end{array}$ & 7 & & & & \\
\hline $\begin{array}{l}\text { Sağa Tehlikeli } \\
\text { Eğim }\end{array}$ & 14 & Köprü Baş1 & 9 & Sağdan Tali Yol & 54 & & & & \\
\hline Sağdan Gidiniz & 3 & $\begin{array}{l}\text { Demiryolu } \\
\text { Geçidi } \\
\text { Yaklaşım }\end{array}$ & 3 & $\begin{array}{l}\text { Sağdan Daralan } \\
\text { Kaplama }\end{array}$ & 71 & & & & \\
\hline $\begin{array}{l}\text { Soruya Yanıt } \\
\text { Vermek } \\
\text { İstemeyen Kişi } \\
\text { Sayısı }\end{array}$ & 72 & $\begin{array}{l}\text { Soruya Yanıt } \\
\text { Vermek } \\
\text { İstemeyen Kişi } \\
\text { Sayıs1 }\end{array}$ & 93 & $\begin{array}{l}\text { Soruya Yanıt } \\
\text { Vermek } \\
\text { İstemeyen Kişi } \\
\text { Sayısı }\end{array}$ & 82 & & & & \\
\hline
\end{tabular}

Katılımcıların trafik işaretlerini doğru cevaplama durumları yaşlarına göre incelendiğinde, en fazla doğru cevapların 18-25 yaş aralığındaki gençlerde ortalama 6, 66-81 yaş aralığındaki katılımcılarda ise ortalama 1 ile en düşük düzeyde olduğu görülür. Yaşlar arasında anlamlı bir fark olduğu $(F(5,644)=3.36, p=0.03)$ bu farkın Tukey sonuçlarına göre 66-81 yaş aralığındaki katılımcılardan kaynaklandığı sonucuna varılır.

"Trafik kurallarına harfi harfine uymak gerekir" sorusunun puan ortalaması $($ Ort. $=2.6, S S=$ 1.28) olarak hesaplanmıştır. Katılımcıların \%65.7'si (427 kişi) kararsız kaldıklarını beyan etmiştir. Cinsiyet $(t=0.79, p=0.43)$, ehliyet sahipliği $(t=0.21, p=0.83)$ ve öğrenim durumunun $(F(5,644)=0.44, p=0.82)$ bu yanıt üzerinde anlamlı bir fark yaratmadığı saptanmıştır (Tablo 4).

"Zamanında varmak için bazen trafik kurallarını esnetmenin bir sakıncası yoktur" sorusunun puan ortalaması $($ Ort. $=2.8, S S=1.14)$ olarak hesaplanmıştır. Katılımcıların \%36'sı (231 kişi) kararsız kaldıklarını beyan etmiştir. Bu soruya verilen cevaplar arasında, cinsiyet $(t=0.48, p=$ $0.64)$, ehliyet sahipliği $(t=1.95, p=0.06)$ ve öğrenim durumunun $(F(5,644)=2.02, p=0.78)$ anlamlı bir fark yaratmadığ 1 saptanmıştır (Tablo 4). 
"Emniyet kemerinin hayati bir önem taşıdığına inanıyorum" sorusuna katılımcıların 2katılmıyorum ve 1-kesinlikle katılmıyorum yanıtlarının toplamı dikkate alındığında, katılımcıların \%66'sı (429 kişi) bu görüşe katılmadıklarını beyan etmiştir. Tüm katılımcıların puan ortalaması $($ Ort. $=2.3, S S=0.87)$ dikkate alındığında katılımcıların emniyet kemerinin hayati bir önem taşımadığı görüşünde oldukları sonucuna varılır. Ehliyet sahipliği $(t=0.26, p$ $=0.82)$ ve öğrenim durumunun $(F(5,644)=1.60, p=0.16)$ bu soru üzerinde anlamlı bir fark yaratmadığı, cinsiyetin ise anlamlı bir fark yarattığ $1(t=2.57, p=0.01)$ saptanmıştır. Bu soruya kadınlar kesinlikle katılmazken, erkekler katılmadıklarını beyan etmiştir (Tablo 4).

"Bazen trafik kurallarının çiğnenmesini göz ardı etmek gerekir" sorusunun puan ortalaması $(O r t .=2.8, S S=0.87)$ dikkate alındığında, katılımcıların bazen trafik kurallarının çiğnenmesi görüşünde kararsız (3 puanla) kaldıkları saptanmıştır. Ehliyet sahipliği $(t=1.71, p=0.08)$ ve öğrenim durumunun $(F(5,644)=1.25, p=0.29)$ bu soru üzerinde anlamlı bir fark yaratmadı ̆̆ cinsiyetin anlamlı bir fark yarattığı $(t=3.08, p=0.02)$ saptanmıştır. Kadınlar bu soruya katılmazken, erkekler bu soruda kararsız kalmıştır (Tablo 4).

"Bir yaya olarak tüm trafik kurallarına harfi harfine uyarım" sorusunun puan ortalaması (Ort. $=2.7, S S=1.22$ ) dikkate alındığında, katılımcıların yaya olarak tüm trafik kurallarına harfi harfine uyma konusunda kararsız kaldıkları saptanmıştır. Bu soruda cinsiyet $(t=0.21, p=$ $0.83)$, ehliyet sahipliği $(t=0.89, p=0.37)$ ve öğrenim durumunun $(F(5,644)=2.1, p=0.70)$ anlamlı bir fark yaratmadığı sonucuna varılır (Tablo 4).

"Trafikte bazen risk almak gerekir" sorusunun puan ortalaması $($ Ort. $=2.8, S S=0.88)$ dikkate alındığında katılımcıların trafikte bazen risk alınması gerektiği görüşünde 3 puanla kararsız kaldıkları saptanmıştır. Bu soruya verilen yanıtlarda cinsiyet $(t=0.39, p=0.72)$, ehliyet sahipliği $(t=0.29, p=0.82)$ ve öğrenim durumunun $(F(5,644)=0.68, p=0.61)$ anlamlı bir fark yaratmadığı sonucuna varılır (Tablo 4$)$.

"Ehliyet alacak kişilerin psikolojik testlerden geçmesi gerektiğine inanıyorum" sorusuna katılımciların, 4-katılıyorum ve 5-kesinlikle katılıyorum yanitlarının toplamı dikkate alındığında \%70.5'inin (458 kişi) bu görüşe katıldıkları görülmektedir. Tüm katılımcıların puan ortalaması $(O r t .=3.8, S S=0.86)$ dikkate alındığında, katılımcıların ehliyet alacak kişilerin psikolojik testlerden geçmeleri gerektiği fikrine katıldıkları saptanmıştır. Cinsiyet $(t=4.51, p$ $=0.59)$, ve öğrenim durumunun $(F(5,644)=0.64, p=0.88)$ bu soru üzerinde anlamlı bir fark yaratmadığ Ehliyet sahibi olanlar bu soruya katıldıklarını, ehliyet sahibi olmayanlar ise bu soruda kararsız kaldıklarını beyan etmiştir (Tablo 4).

"Trafik işaretlerinin gereksiz yere fazla olduğunu düşünüyorum" sorusuna katılımcıların 4katılıyorum ve 5-kesinlikle katılıyorum yanıtlarının toplamı dikkate alındığında katılımcıların \%66'sının (429 kişi) bu görüşe katıldıkları görülmektedir. Tüm katılımcıların puan ortalaması $(O r t .=4.1, S S=0.88)$ dikkate alındığında katılımcıların trafik işaretlerinin fazla olduğu fikrine katıldıkları saptanmıştır. Bu soruda cinsiyet $(t=0.17, p=0.86)$, ehliyet sahipliği $(t=0.53, p$ $=0.59)$ ve öğrenim durumunun $(F(5,644)=1.87, p=0.10)$ anlamlı bir fark yaratmadığ sonucuna varılır (Tablo 4).

"Trafik kazalarının bir kader olduğuna inanıyorum" sorusuna katılımcıların 4-katılıyorum ve 5kesinlikle katılıyorum yanıtlarının toplamı dikkate alındığında katılımcıların \%67'sinin (435 kişi) bu görüşe katıldıkları görülmektedir. Tüm katılımcıların puan ortalaması $($ Ort. $=3.9, S S=$ 0.89) dikkate alındığında, katılımcıların 4 puanla trafik kazalarının kader olduğu düşüncesine katıldıkları saptanmıştır. Bu soruya verilen yanıtlar incelendiğinde, cinsiyet $(t=0.27, p=0.78)$ ve öğrenim durumunun bu soruda $(F(5,644)=0.44, p=0.88)$ anlamlı bir fark yaratmadığ

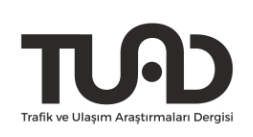


ancak ehliyet sahipliği dikkate alındığında ehliyeti olmayanların bu fikirde kararsız kalırken, ehliyet sahibi olanların bu fikre katıldıkları $(t=2.32, p=0.02)$ saptanmıştır (Tablo 4).

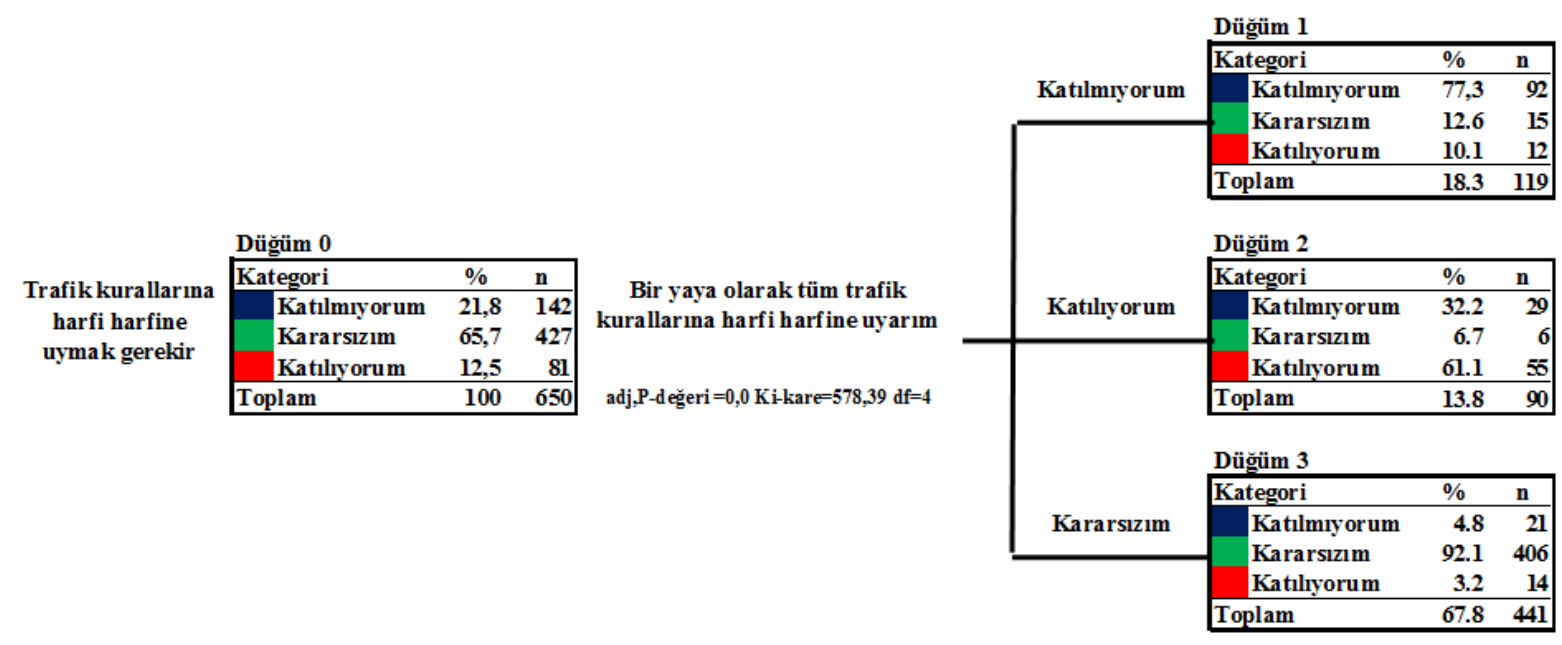

Şekil 1. CHAID algoritması ile oluşturulan karar ăgacı I

Katılımcıların trafik kurallarına uyma düşüncelerini biraz daha belirgin olarak ortaya çıkarabilmek amacıyla, trafik kurallarına uyma düşüncelerini içeren üç soruya ait karar ağacı uygulamasına yer verilmiştir. CHAID algoritması ile oluşturulan karar ağacına göre "Trafik kurallarına harfi harfine uymak gerekir" ifadesinde 427 kişi (\%66) kararsız olduklarını belirtmiş̧tir. Oluşturulan ağaca göre, dallanma işleminde "Bir yaya olarak tüm trafik kurallarına harfi harfine uyarım" sorusuna 441 kişinin (\%68) kararsız olarak cevap verdiği, 119 kişinin (\%18) katılmadığı ve 90 kişinin (\%14) bu fikre katıldıkları saptanmıştır. Her iki düşüncede de kararsız kalan 406 kişi bulunmaktadır (Şekil 1).

\begin{tabular}{|c|c|c|c|c|}
\hline \multirow{6}{*}{$\begin{array}{c}\text { Trafik kurallarina } \\
\text { harfi harfine } \\
\text { uymak gerekir }\end{array}$} & \multicolumn{3}{|l|}{ Düğüm 0} & \multirow{5}{*}{$\begin{array}{l}\text { Zamanında varmak için bazen } \\
\text { trafik kurallarını esnetmenin } \\
\text { hiçbir sakncası yoktur }\end{array}$} \\
\hline & Kategori & $\%$ & $\mathbf{n}$ & \\
\hline & Katılmryorum & 21,8 & 142 & \\
\hline & Kararsizım & 65,7 & 427 & \\
\hline & Katılyyorum & 12,5 & 81 & \\
\hline & Toplam & 100 & 650 & adj,P-değeri $=0,0 \mathrm{Ki}$-kare $=581,65 \mathrm{df}=4$ \\
\hline
\end{tabular}

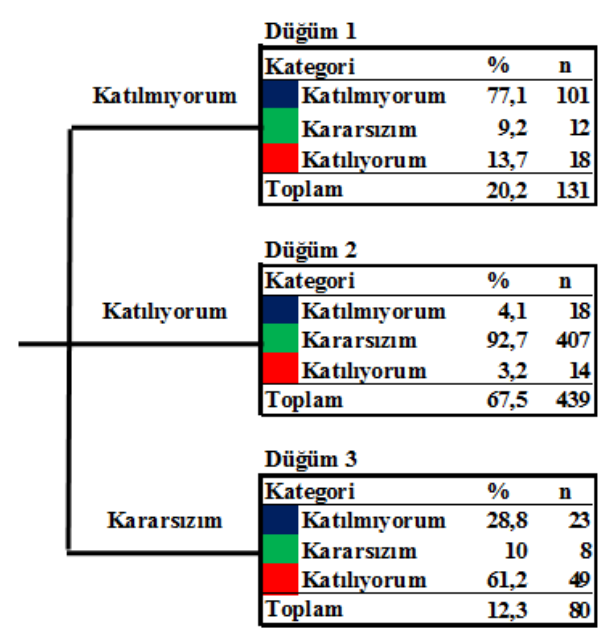

Şekil 2. CHAID algoritması ile oluşturulan karar ă̆acı II

Oluşturulan ikinci ağaca göre "Zamanında varmak için bazen kuralları esnetmenin hiçbir sakıncası yoktur" sorusuna katılımcılardan 439 kişi (\%68) katılırken, 131 kişi (\%20) bu fikre katılmadıklarını belirtmiştir (Şekil 2). 


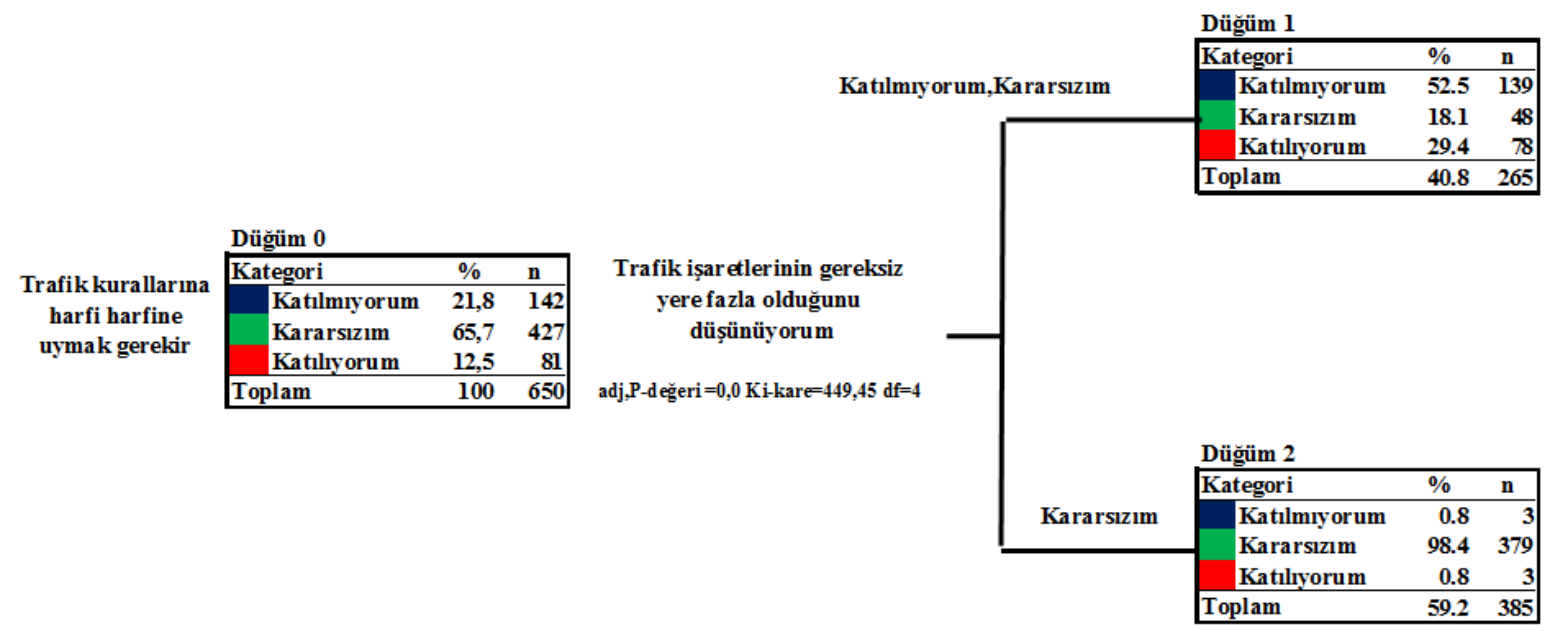

Şekil 3. CHAID algoritması ile oluşturulan karar ă̆acı III

Oluşturulan üçüncü ağaca göre "Trafik işaretlerinin gereksiz yere fazla olduğunu düşünüyorum" sorusuna katılımcılardan 385 kişi (\%59) kararsız olduklarını ifade etmiştir (Şekil 3).

\section{Tartışma ve Sonuç}

Günümüzde trafik kazalarında her yıl binlerce insanımızı kaybetmekteyiz. Medyada "Trafik Kazaları" başlıklarının yerini "Trafik Terörü" başlıkları almaktadır. Ülkemizde trafik güvenliği konusuna çözümler üretebilmek için trafikte yer alan sürücü ve yayalar hakkında bilgi sahibi olmamız gerekir. Bu kapsamda Van ilinde yaşayan bireylerle yapılan görüşmeler sonucunda bu bireylerin trafiğe ve trafik işaretlerine bakışlarından şu bilgilere ulaşılmıştır. Katılımcıların \%68'i trafik işaretlerini okuma ve anlama becerisine sahip değildir. Çalışmada sorulan 18 trafik işaretinden 9'unu bilen kişi oranı \%70 iken 18 trafik işaretini bilen kimseye rastlanmamıştır. Cinsiyetler bakımından incelendiğinde, trafik işaretlerini bilme konusunda erkeklerin kadınlardan daha iyi oldukları saptanmıştır.

Katılımcıların öğrenim durumları ile trafik işaretlerini doğru bilme sayısı arasında anlamlı bir fark olduğu ve bu farkın üniversite/y.okul mezunlarından kaynaklandığı saptanmıştır. Bu sonuç, katılımcıların büyük çoğunluğunun genç olması, öğrenme süreçlerinin devam etmesi ve hafızalarının hala taze olması düşüncesini doğurur. Trafik işaretlerini doğru bilme sayısında yaşın anlamlı bir fark yarattığı sonucuna varılır. Bu sonuç genç katılımcıların trafik işaretlerini hatırlaması konusunda daha önce yapılan çalışmalardaki (Al-Madani ve Al-Janahi, 2002; Razzak ve Hasan, 2010; Shinar ve ark., 2003) sonuçlarla benzerlik göstermiştir. Gençlerin daha canlı bir hafızaya sahip olmaları, ehliyet sınavına yakın zamanda girmeleri ve sınav için hazırlık yapmalarından dolayı bilgilerinin daha güncel olduğu sonucu çıkarılır.

Ehliyet sahipliği trafik işaretlerini bilme düzeyinde anlamlı bir fark yaratmıştır. Ehliyet sahibi olanların ehliyet sınavları için trafik işaretlerini öğrenmek zorunda kalmaları ve trafiğe çıkan ehliyet sahiplerinin kurallara uyma zorunluluğundan dolayı trafik işaretlerine daha fazla aşina oldukları sonucu çıkarılır.

"Trafik kurallarına harfi harfine uymak gerekir" ifadesine katılımcılar kararsız kalırken, "Bir yaya olarak tüm trafik kurallarına harfi harfine uyarım" ifadesinde de katılımcıların kararsız kaldıkları, bu görüşlerde ehliyet sahipliği, öğrenim durumu ve cinsiyetin anlamlı bir fark yaratmadığı saptanmıştır.

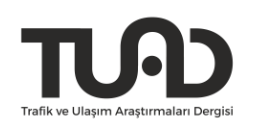


"Zamanında varmak için bazen trafik kurallarını esnetmenin bir sakıncası yoktur" ifadesine katılımcıların kararsız kaldıkları, bu görüşlerde cinsiyet, ehliyet sahipliği ve öğrenim durumunun anlamlı bir fark yaratmadığı saptanmıştır.

"Emniyet kemerinin hayati bir önem taşıdı̆̆ına inanıyorum" ifadesine katılımcılar katılmadıklarını belirtirken, erkekler bu fikre katılmadıklarını, kadınlar ise kesinlikle katılmadıklarını belirtmiştir. Ancak emniyet kemeri kazaların ölümle sonuçlanma ihtimalini azaltan basit ve etkili bir önlemdir (EGM, 2016). Ortadoğu Teknik Üniversitesi ile Emniyet Genel Müdürlüğü'nün ortak bir çalışması olan “Türkiye Analizi: Sürücü ve Ön Koltuk Yolcularının Emniyet Kemeri Kullanımı" başlıklı rapordaki istatistiklerden de anlaşılacağı üzere Van ilinde sürücülerde emniyet kemeri kullanım oranı $\% 8$ (şehir içinde emniyet kemeri kullanma oran $1 \% 4.8$, şehirlerarası yollarda emniyet kemeri kullanma oranı \%21.9) yolcularda bu oran \%3.6 (şehir içinde emniyet kemeri kullanma oranı \%2.1, şehirlerarası yollarda emniyet kemeri kullanma oranı \%8.4) olarak saptanmıştır. Van ili, emniyet kemeri kullanımı genel ortalaması 0-25 yüzdelik diliminde tespit edilen 29 il arasında ve tüm Türkiye'de hem sürücüler hem de yolcuların emniyet kemeri kullanım oranları sıralamasında en sonda yer almıştır (EGM, 2016). Her ne kadar araç sürücülerinin ve yolcuların trafikte emniyet kemeri takmaları yasalar gereğince zorunlu olsa da, şehirde karşılaşılan emniyet kemeri ikaz sesini susturmak amaciyla kullanılan emniyet tokaları ya da koltuğun arkasından bağlanan emniyet kemeri uygulamaları "Türkiye Analizi: Sürücü ve Ön Koltuk Yolcularının Emniyet Kemeri Kullanımı" rapor sonuçlarını destekleyici yöndedir.

"Ehliyet alacak kişilerin psikolojik testlerden geçmesi gerektiğine inanıyorum" ifadesine katılımcılar katıldıklarını belirtmiştir. Ehliyet sahibi olanlar bu soruya katılırken, ehliyet sahibi olmayanlar kararsız olduklarını beyan etmiştir. Bugün ülkemizde kullanılan "trafik canavarı" terimi kural ihlalleri yapan ya da trafikte öfkesini kontrol edemeyen sürücüler için kullanılmaktadır. Bu soruya katılımcıların bu kadar yüksek oranda katılım göstermelerinin sebebi, ehliyet sahibi sürücülerin trafikte maruz kaldıkları olaylar olduğu düşüncesini doğurur.

"Trafik işaretlerinin gereksiz yere fazla olduğunu düşünüyorum" ifadesine katılımcılar katıldıklarını beyan etmiştir. Bu düşüncenin cinsiyet, yaş ve öğrenim durumlarına göre anlamlı bir fark göstermediği saptanmıştır.

"Trafik kazalarının bir kader olduğuna inanıyorum" ifadesine verilen yanıtlara göre erkekler ve ehliyet sahibi olanlar bu fikre katılırken, kadınlar ve ehliyet sahibi olmayanların kararsız kaldığı saptanmıştır. Kader, olayların önceden ve değişmeyecek biçimde düzenlendiğine inanılan olay ya da olaylar zinciridir. Trafikte hız sınırını aşmak, trafik kurallarına uymayarak riskli hareketlerde bulunmak trafik kazalarına davetiye çıkarmak olarak nitelendirilir. $\mathrm{Bu}$ anlamda katılımcılar trafikte araç kullananların hız sınırlarına ya da trafik kurallarına uymaları durumunda bile kaderlerinde varsa trafik kazası geçireceklerine olan inançlarını göstermektedir. Bu soruya verilen yanıtlar ileride irdelenirken bölge insanının sosyolojik yapısı göz ardı edilmemelidir.

"Bazen trafik kurallarının çiğnenmesini göz ardı etmek gerekir" ve "Trafikte bazen risk almak gerekir" ifadelerine katılma konusunda katılımcılar kararsız olduklarını beyan etmiştir. Risk alma ile ilgili ifadeye verilen yanıtlarda cinsiyet, öğrenim durumu ve ehliyet sahibi olmanın anlamlı bir fark yaratmadığı, kuralların çiğnenmesi ile ilgili ifadeye ise kadınların katılmadığı saptanmıştır. $\mathrm{Bu}$ durum, halk arasında kadınların trafik kurallarına uyan sürücüler olarak tanımlanmalarını destekler durumdadır.

Genel olarak bakıldığında bu çalışma, Van ilinde yaşayan (sürücü ve yaya) bireylerin trafik işaretleri ile ilgili bilgi ve trafik kurallarına bakış açılarının değerlendirilmesi açısından önemlidir. Bu çalışmanın sonunda katılımcıların trafik işaretlerini bilme düzeylerinin yetersiz,

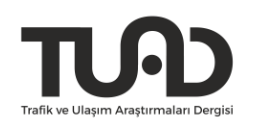


trafik kurallarına uyma konusunda ise kararsız ve kuralları ihlal etmeye meyilli oldukları saptanmıştır. Çalışmada sorulmamış sorular bu kararsızlığın nedenleri hakkında yorum yapmamıza engel olmaktadır. İleride bu konuda çalışacak araştırmacıların bu eksik kalan bölümleri dikkate almaları yararlı olacaktır. 


\section{Kaynakça}

Al-Madani, H. ve Al-Janahi A-R. (2002). Role of drivers' personal characteristics in understanding traffic sign symbols. Accident Analysis and Prevention, 34(2), 185-196. doi:10.1016/S0001-4575(01)00012-4

Arıkan Öztürk, E. (2016). Türkiye'deki illerin trafik risk endeksi. Pamukkale Üniversitesi Mühendislik Bilimleri Dergisi, 22(6), 405-412.

Birgün (2018). Erişim Adresi: https://www.birgun.net/haber-detay/tbmm-dilekce-altkomisyonundan-trafik-raporu-200142.html, Erişim Tarihi: 15.03.2018

Emniyet Genel Müdürlüğü (2016). Türkiye analizi: Sürücü ve ön koltuk yolcularının emniyet kemeri kullanımı raporu. Erişim adresi: http://www.trafik.gov.tr/SiteAssets/Yayinlar/ Kitaplar/Emniyet\%20Kemeri\%20Nihai \%20Rapor.pdf. Trafik Hizmetleri Başkanlığı, Erişim Tarihi: 30.10 .2018

Emniyet Genel Müdürlügü (2017a). Trafik istatistik bülteni, ülke geneli, 2017 yılı. Erişim Adresi: http://www.trafik.gov.tr/SiteAssets/istatistik/2017s.pdf, Trafik Eğitim ve Araştırma Dairesi Başkanlığı, 2017. Erişim Tarihi: 30.10.2018

Emniyet Genel Müdürlüğü (2017b). Araç ve sürücü belgesi istatistikleri. Erişim Adresi: http://www.trafik.gov.tr/SiteAssets/istatistik/Arac_Surucu.pdf, Trafik Eğitim ve Araştırma Dairesi Başkanlığı, 2017. Erişim Tarihi: 30.10.2018

Eşiyok, B., Yasak, Y. ve Korkusuz, İ. ( 2007) Trafikte öfke ifadesi: Sürücü Öfke İfadesi Envanteri'nin geçerlik ve güvenilirliği. Türk Psikiyatri Dergisi, 18(2), 1-13.

Girgin, V. ve Kocabıyık, A. (2003)."Kazaya Yatkınlık" tanımı yapılabilir mi, "Riskli Sürücü"ler kimlerdir?. Düşünen Adam, 16(1), 35-38.

Karabağl1, H. (15 Ocak 2018). Türkiye'de her 11 aileden biri trafik mağduru; yaşamını yitiren her 100 yayadan 26'sı çocuk. T24. Erişim Adresi: http://t24.com.tr/haber/turkiyede-her11-aileden-biri-trafik-magduru-yasamini-yitiren-her-100-yayadan-26si-cocuk,536139. Erişim Tarihi: 15.03 .2018

Kartal, C. ve Batmaz, İ. (2007). Ankara bölgesi il sınırlarında bulunan trafik kontrol işaretlerinin fonksiyonerliğinin değerlendirilmesi. Politeknik Dergisi, 10(1), 59-70.

Kazemi, M., Rahimi, A. M. ve Roshankhah, S. (2016). Impact assessment of effective parameters on drivers' attention level to urban traffic signs. Journal of The Institution of Engineers (India): Series A. 97(1), 63-69. doi:10.1007/s40030-016-0145-3

Kırmızıoğlu, E. ve Tüydeş-Yaman, H. (2012). Comprehensibility of traffic signs among urban drivers in Turkey. Accident Analysis and Prevention, 45, 131-141. doi:10.1016/j.aap.2011.11.014

Luoma, J. ve Rama, P. (1998). Effects of variable speed limits on speed behaviour and recall of signs. Traffic Engineering and Control, 39, 234-237.

Mevzuat, T.C. Cumhurbaşkanlığı Hukuk ve Mevzuat Genel Müdürlüğü (2018). Erişim Adresi: www.mevzuat.gov.tr/ MevzuatMetin/1.5.2918.doc. Erişim Tarihi: 15.03.2018

Murat, Y. Ş. ve Çakıcı, Z. (2017). Trafik işaretlerinin bilinirliği üzerine bir araştırma: Denizli örneği. BEÜ Fen Bilimleri Dergisi, 6(1), 21-30. 
Ng, A. W. Y. ve Chan, A. H. S. (2008). The effects of driver factors and sign design features on the comprehensibility of traffic signs. Journal of Safety Research, 39(3), 321-328.

Nordfjaern, T. ve Şimşekoğlu,Ö. (2014). Empathy, conformity, and cultural factors related to aberrant driving behaviour in a sample of Urban Turkish drivers. Safety Science, 68, 5564.

Öztürk, İ. ve Özkan, T. (2018). Genç sürücülerde sürücü becerileri ve sürücü davranışları arasındaki ilişki. Trafik ve Ulaşım Araştırmaları Dergisi, 1(2), 1-15.

Razzak, A. ve Hasan,T. (2010). Motorist understanding of traffic sign: A study in Dhaka city. Journal of Civil Engineering, 38(1), 17-29.

Reason, J., Manstead, A., Stradling, S., Baxter, J. ve Campbell, K. (1990). Errors and violations on roads. Ergonomics, 33, 1315-1332.

Shinar, D., Dewar, R. E., Summala, H. ve Zakowska, L. (2003). Traffic sign symbol comprehension: A cross-cultural study. Ergonomics, 46(15), 1549-1565, doi:10.1080/0014013032000121615

Şehribanoğlu, S. ve Diler, S. (2018). 2013 yılı yaşam memnuniyeti araştırmasının CRT ve CHAID algoritmaları ile incelenmesi. Uluslararası Sosyal Bilimler Dergisi, 67, 132141.

TÜİK (2018). Türkiye Istatistik Kurumu. http://www.tuik.gov.tr. Erişim Tarihi: 10.02.2018

Yakut, S. (2006). Trafik işaretlerinin algılanabilirliği (Yayımlanmamış Yüksek Lisans Tezi). Gazi Üniversitesi, Ankara.

Yıldız, M.C. ve Karaca M. (2004, Mayıs). Otomobil Sürücülerinin Trafik ve Yol Güvenliği Konusundaki Görüşlerine Sosyolojik Bakış. Trafik ve Yol Güvenliği II. Uluslararası Kongresi, Ankara.

Y1lmaz, V. ve Çelik, H.E. (2006). Risky driving attitudes and self-reported traffic violations among Turkish drivers: The case of Eskişehir. Doğuş Üniversitesi Dergisi, 7(1), 127138 .

Ulleberg, P.ve Rundmo, T. (2003). Personality, attitudes and risk perception as predictors of risky driving behavior among young drivers. Safety Science, 41, 427-443.

Üngüren, E. ve Doğan, H. (2010). Beş yıldızlı konaklama işletmelerinde çalışanların iş tatmin düzeylerinin CHAID analiz yöntemiyle değerlendirilmesi. CÜ İktisadi ve İdari Bilimler Dergisi, 11(2), 39-52.

Dünya Sağlı Örgütü (2017). Road traffic injuries. Erişim Adresi: http://www.who.int/mediacentre/factsheets/fs358/en. Erişim Tarihi: 08.02.2019

Zhang, T. ve Chan, A. H. S. (2013). Traffic sign comprehension: A review of influential factorsand future directions for research. Proceedings of the International MultiConference of Engineers and Computer Scientists. Vol II, IMECS 2013, March 13-15, Hong Kong. 